\title{
Students' Perceptions on the Implementation of Online Learning in Pandemic Era
}

\author{
Homsatul Istiqomah ${ }^{1}$, Mochammad Hatip ${ }^{2}$, Henri Fatkurochman ${ }^{3}$, and Fitrotul \\ Mufaridah $^{4}$ \\ 1,2,3,4 Universitas Muhammadiyah Jember, Indonesia \\ (mufaridah@unmuhjember.ac.id)
}

\begin{abstract}
The implementation of online learning in Indonesia today becomes an alternative to conventional learning because of the pandemic situation. However, it triggers some problems during the learning process. The problems exist because of various aspects. One of them is the way how the teachers implement the learning process. This research is aimed to investigate how students perceive the online learning implementation in higher education based on four categories, namely Planning \& Promotion, Education, Support \& Training, and Encouragement. It is descriptive-survey research using a questionnaire as the instrument to collect the data. The result shows various perceptions of students. The average students perceive: 1) implementation of online learning is well planned, 2) the lecturers are competent enough in implementing the online learning, 3) they receive sufficient support during the online learning, and 4) the online learning situation encourages them in the learning process. Based on the finding, it can be concluded that online learning situation and interaction in their study program have encouraged them to learn The findings of the study can be used as an evaluation for the stakeholders (lecturers and decision-makers) for the online learning implementation. The study is limited to only one study program in a private university. Further studies are therefore encouraged to study a wider context.
\end{abstract}

Keywords: Distance learning; implementation; online learning; students' perceptions; teaching English.

The implementation of online learning in higher education now becomes an obligation because of the current situation that makes people should limit their face-to-face interactions. Consequently, the conventional teaching-learning process should be changed into online mode which is different from offline characteristics in some aspects. In fact, the implementation of online learning that happens suddenly can cause some problems faced by the students who have no much experience and preparation from the beginning.

The psychological problem is one of the issues which being an interesting topic to 
discuss. Study-related to academic stress of university students in Indonesia during the online learning declared that the majority of 204 college students got academic stress in the medium category ( 80 students), 55 students were in the high category, 48 students were in a low category, 14 students were in the very high category, and 11 students were in very low category (Lubis et al., 2021). In contrast, studies related to students' perceptions of online learning, especially the use of online learning platforms which was conducted to university students showed that it is effective and getting positive perceptions of the students (Bagata et al., 2020). In India higher education context, students perceive usefulness form and positive attitude on the use of collaborative platform in online learning (Singh et al., 2020). Thus, it is agreed that the use of online learning platforms shares positive perceptions.

Based on those studies, students' perception on the online learning implementation remains debatable. The findings show that students have positive perceptions of the use of online learning platforms, but they feel anxiety during the online learning. So it is needed to conduct a study which not only focuses on the use of online learning platforms, but also on the students' perceptions of online learning implementation from different aspects.

Regarding the issue of students' perception of online learning implementation, this study examines six stages in implementing online learning proposed by Jones (2008). They are Planning \& Promotion, Education, Support, Training, Encouragement, Recognition and Reward (PESTER). The stages are pointed to educators, and every single stage provides contribution on the success category of online learning implementation.

The first stage is a definite plan of how and why online learning could be implemented in accordance with overall institution plans. It is an important stage needed towards a successful implementation. This step should be continued by encouraging that plan and its benefits for students, staff or educators, and institutions.

After having a good planning and promotion, the second stage needed to prepare is education. Education refers to the educators' ability in implementing the online learning including the appropriate model for a certain context, and the way they use the technology to deliver the subject during the online learning. This step is obviously significant for having a competent educator to do the pedagogical and technological aspects, and to minimize the problems in online learning implementation.

Then, the third stage is support. The competency of educators should be followed by the support given by the institutions for both, the students and the educators. The support can be formulated in network access, mentor and group discussion.

The fourth stage is training. This step is providing appropriate training in technology and pedagogy. Training in technology includes the use of proper and interesting technology such as the use of interactive online communication (Padlet, Jamboard, Nearpot) and virtual conference platforms in order to ensure the implementation of online learning can run well.

The fifth step is encouragement. This step can be provided to educators by time allocation for joining the training. It is also about appreciation to educators in designing, developing and maintaining the online learning activities in order to increase students' participations during the online learning.

The last stage is recognition and reward. Recognition is given for the time and resources allocated for designing and developing actual online learning materials. Reward is given for educators for performing online class in advantage. So, recognition and reward is worthy for the educators who have implemented online teaching and learning initiatives properly. 


\section{Perception}

In Longman Dictionary of Contemporary English, the term 'perception' is defined as: a) the way you think about something and your idea of what it is like; b) the way you notice things with your senses of sight, hearing etc.; c) the natural ability to understand or notice things quickly. Based on this definition, it can be infered that 'perception' is the way to view and understand something .

In philosophy, psychology, and cognitive science, 'perception' is defined as a process of attaining awareness or understanding of sensory information (Qiong, 2017). Moreover, he stated that it derived from Latin words perceptio, percipio, meaning "receiving, collecting, action of taking possession, and apprehension with the mind or sense."

For instance, although theory-driven research methodologies are very useful for examining the relationship of two social phenomena (e.g., the relationship between social groups and educational achievement), such methodologies typically cannot provide deeper insight into why such a relationship exists (e.g., why and/or how social groups relate to educational achievement). Given such a limitation, Glaser and Strauss (1967) propose grounded theory as alternative methodology for advancing the field of social sciences. That is, unlike theory-driven research methodologies, grounded theory encourages data-driven research practices that potentially lead to theory construction to help explain why and/or how certain social phenomena occur.

\section{Students' Perception}

Students' perceptions on online learning have been found in some studies. Those studies mostly focused on the use of platform for synchronous and asynchronous activities. The studies gathered students' perceptions on the online learning platform utilization, not the online learning implementation in general.

Students' perceptions of online learning not only focus on the platforms used, but also on the learning process and the support obtained by students. A study conducted by Puspaningtyas \& Dewi (2020) to senior high school students showed that students got sufficient support for online learning implementation from their school and their family. In terms of technical indicator, majority of students have a problem related to the signal of internet and the application used during the online learning process. It made the students be frustrated with the difficulty to communicate with the teacher. Because of those kinds of barriers, students sometimes prefered have face-to-face to online learning interaction. In addition, students also had difficulty to understand the materials by reading the book only, they need further guidance, information or explanation to have better understanding.

Higher education students are expected to be more independent than senior high school students. But it does not mean that higher education students do not have any obstacles during the online learning. The problems could come from many aspects. There are three major obstacles faced by the students, they are availability and sustainability of internet connection, accessibility of the teaching media, and the compatibility of tools to access the media (Agung \& Surtikanti, 2020). One of them is about the way the online learning implemented in their college or university. The problem can be prevented by doing wellplanned preparation. If the stakeholders, in this case the lecturers and the decision makers of online learning implementation, have made a well-planned online learning implementation, the obstacle faced by students can be minimized. Thus, it is important to carry out and ensure whether the implementation of online learning in college or university institution has been well-planned or not. This research is aimed at describing university students' perceptions of online learning implementation that focuses on four subcategory of online learning implementation (Planning \& Promotion, Education, Support, and Encouragement). The result of this study 
is expected to be used as an evaluation for the stakeholders who are responsible to the implementation of online learning.

\section{Method}

This is descriptive-survey research about students' perceptions on the implementation of online learning on language teacher students. In survey research, investigators ask questions about peoples' beliefs, opinions, characteristics, and behavior (Ary et al., 2010). In this research, the researcher asked questions about students' opinions related to online learning implementation in their faculty.

The study was conducted in September

2021. It involved 80 university students consists of 30 students of academic year 2018, 27 students of academic year 2019, and 23 students of academic year 2020. The students have experienced the online learning at least one year.

The data were collected using questionnaire. The questionnaire was constructed based on the four stages of online learning implementation adapted from Jones (Jones, 2008). The questionnaire is five-Likert scale which consists of 15 closed-ended questions. The questionnaire was distributed in form of google form link. It is used to find out students' perceptions of the online learning implementation in their faculty which focusing on the planning \& promotion, education, support, training, and encouragement.

Validity of the questionnaire was tested using Pearson correlation in SPSS. It is done by correlating each item scores in the questionnaire with the total score. If the significance value of the item is less than 0.05 , then the item is valid. If the significance of the item is more than 0.05 , then the item is invalid. Afterward, the valid item was tested using Cronbach's Alpha to test the reliability. In most social science research situations, if the alpha coefficient is 0.7 or higher, it is considered "acceptable". So, if the alpha coefficient is lower than 0.7 , then the instrument's reliability is not good enough. The Cronbach's Alpha coefficient of the questionnaire used in this research was 0.869 , meaning that the reliability was acceptable. The data from the questionnaire was analyzed statistically using descriptive statistics, frequencies in SPSS.

\section{Results and Discussion}

Based on the questionnaire of students' perceptions on online learning implementation which consists of 4 sub-categories (Planning \& Promotion, Education, Support, and Encouragement), the data is described and analyzed in those four sub categories. The data obtained can be seen in Table 1 .

Table 1. Means of Student's Perception $(n=80)$

\begin{tabular}{lll}
\hline Sub Categories & Mean & SD \\
\hline Planning & 3,06 & 0,68 \\
Education & 3,02 & 0,81 \\
Support \& & 3,30 & 1,09 \\
training & & \\
Encouragement & 3,42 & 0,63 \\
\hline Total & 3,19 & 0,64 \\
\hline
\end{tabular}

In the first sub-category, students' perceptions on how well is the planning and promotion of online learning, the mean score were 3.06 with scale $1-5$ which is 1 means very unwell-planned and not interesting, 3 means well-planned and interesting, and 5 means very well-planned and very interesting. This result means that students recognize the lecturer do online learning and teaching with a real planning.

In the second sub-category, education, students give their perceptions on how the lecturers' competencies in the subject learned and their digital literacy of the platforms used during the online learning. The mean score was not really different from the first sub category. It was 3.02 ( 1 = very incompetent, 3 = fair, $5=$ very competent). It means that students think the lecturers are competent enough in delivering the content and using the digital 
platform.

In the third sub-category, support and training, the mean was increasing from the first and the second sub-category. It was $3.30(1=$ very unsupported, $3=$ fair, $5=$ very supported). It means students' perceptions in the third category were higher than the first and the second and the standard deviation was also bigger. In this sub-category, support and training, the standard deviation score is 1.09 , then in the other sub-categories the standard deviations are 0.68 in planning, 0.81 in education, and 0.63 in encouragement. It means that students' perceptions are having more variation than the two previous categories.

The highest mean was obtained on the fourth category, encouragement. It was $3.42(1=$ very discouraged, $3=$ fair, $5=$ very encouraged). This shows that students perceive the situation and interaction during the online learning have encouraged them to be actively involved in learning process. The students get their motivation to follow the class with the encouraging atmosphere conveyed by the lecturer. In this category, the standard deviation shows the lowest score. It means that students' perceptions on encouragement were likely the same.

The findings of this study deliver interesting online teaching and learning implementation considering to students' perception on four sub categories. This survey study provides different actual implementation of online teaching and learning in higher education level by involving one study program at one university.

The first finding of this study is related to the planning and promotion of the online learning implementation done by the lecturers. Since the students join the class, their experiences bring them to perceive the online class runs well with planning and promotion the lecturer set out for success implementation. The students' perception is reflecting how serious the lectures prepare the online teaching and learning. Bates and Poole
(2003) stated that the definite plan of how the online learning will be implemented is needed for the successful implementation. So, planning is not routine step without goal, but more than that, a lecture should strive planning before teaching to realize the important of success in online teaching and learning implementation. Moreover, Rieley (2020) stated that planning is an urgent need for the academic institutions during the pandemic situations. In this study, the result proves that the students perceive the implementation of online learning is wellplanned. It is even not only well-planned, but students also perceive the implementation of online learning as an interesting learning.

The second finding is related to lecturers' competency in implementing online learning in term of pedagogy and technology aspect. Better competency the lecturers have can be reasonable guaranty to realize and deliver successful online implementation. Lecturers have direct and important influences on the students' learning experience (Do et al., 2021). The online learning situation which need more specific efforts rather than the conventional learning, takes a fundamental requirement for lecturers to have qualified competences. Lecturers with qualified competency, of course, can contribute much in encouraging the students achieve the learning objectives through online learning activity. Based on the finding, the students perceive the lecturers' competence during the online learning in an average score. It means that the lecturers' competences are moderate.

Related to the third finding about support and training, this study state that providing guidance and support on how to use and access the online learning content are lecturers' job for students. A lecturer should motivate students to be optimist in learning and lead them to have better skill through online learning. Those can be critical work in implementing online learning (Ali, 2020). In this study, students perceive the support and training provided by the lecturers on their study program in average score, meaning that 
they have got enough support and training during the online learning process.

In the fourth finding, it is about students' perceptions on how do the online learning encourage them to learn. Creating an environment that encouraged learner input and fostered sharing of ideas was conducive to learning (Tough \& Knowles, 1985). Based on the finding, it can be concluded that online learning situation and interaction in their study program have encouraged them to learn.

\section{Conclusion}

This study focuses on the students' perceptions on the online learning implementation during the covid-19 pandemic. Based on the findings and discussion, students perceive the implementation of online learning in their study program in various ways. The average students perceive: 1) implementation of online learning is well planned, 2) the lecturers are competent enough in implementing the online learning, 3) they got enough support during the online learning, and 4) the online learning situation encourages them in learning process. The findings are evaluative perception to take as feedback to reconstruct and perform better on the implementation of online learning. This study is only involved one study program in a private university. It will be interesting if it is being studied in the wider context.

\section{Acknowledgment}

We deeply thank the respondents who have been investing their time to participate on this study.

\section{References}

Agung, A. S. N., \& Surtikanti, M. W. (2020). Students' Perception of Online Learning during COVID-19 Pandemic: A Case Study on the English Students of STKIP Pamane Talino. SOSHUM: Jurnal
Sosial Dan Humaniora. https://doi. org/10.31940/soshum.v10i2.1316

Ali, W. (2020). Online and Remote Learning in Higher Education Institutes: A Necessity in light of COVID-19 Pandemic. Higher Education Studies. https://doi. org/10.5539/hes.v10n3p16

Ary, D., Jacobs, L. C., Sorensen, C., \& Razavieh, A. (2010). Introduction to Rsearch in education, 8th Edition (8th ed.). Wadsworth Cengage Learning.

Bagata, D. T. R., Umamah, A., \& Fikri, D. (2020). EFL University Students' Perception of the Use of Online Learning Platform in the Covid 19 Pandemic. Jurnal Penelitian, Pendidikan, Dan Pembelajaran UNISMA.

Bates, A. W., \& Poole, G. (2003). A Framework for Selecting and Using Technology. In Effective teaching with technology in higher education: Foundations for success. In John Wiley \& Sons, Inc. San Francisco.

Do, T. T. M., Ngo, T. V., Hoang, Q. A., Nguyen, G. T. L., Truong, N. D., Le, H. M., Vo, N. T., Ruhalahti, S., \& Kunnari, I. (2021). Evaluating Online Learning and Teaching at the University of Technology and Education Ho Chi Minh City During Coronavirus Pandemic. Journal of Technical Education Science, 62(02), 18-27.

Jones, H. (2008). Pestering staff into online learning: An integrated plan for implementation. ASCILITE 2008 - The Australasian Society for Computers in Learning in Tertiary Education.

Lubis, H., Ramadhani, A., \& Rasyid, M. (2021). Stres Akademik Mahasiswa dalam Melaksanakan Kuliah Daring Selama Masa Pandemi Covid 19. Psikostudia : Jurnal Psikologi. https://doi. org/10.30872/psikostudia.v10i1.5454 
Puspaningtyas, N. D., \& Dewi, P. S. (2020). Persepsi Peserta Didik Terhadap Pembelajaran Berbasis Daring. Jurnal Pembelajaran Matematika Inovatif (JPMI).

Qiong, O. (2017). A Brief Introduction to Perception. Studies in Literature and Language.

Rieley, J. B. (2020). Corona Virus and its impact on higher education. In Research Gate.

Singh, A., Sharma, S., \& Paliwal, M. (2020). Adoption intention and effectiveness of digital collaboration platforms for online learning: the Indian students' perspective. Interactive Technology and Smart Education. https://doi. org/10.1108/ITSE-05-2020-0070

Tough, A., \& Knowles, M. S. (1985). Andragogy in Action: Applying Modern Principles of Adult Learning. The Journal of Higher Education. https:// doi.org/10.2307/1981081 